\title{
Aspirin plus Pseudoephedrine (Aspirin Complex) for the Treatment of Symptoms of Upper Respiratory Tract Infection
}

\author{
Michael Voelker¹, Ronald Eccles ${ }^{2}$, Uwe Gessner ${ }^{1}$ \\ ${ }^{1}$ Bayer AG, Leverkusen, Germany \\ ${ }^{2}$ Common Cold Centre, Cardiff University, Cardiff, UK \\ Email:michael.voelker@bayer.com
}

How to cite this paper: Voelker, M., Eccles, R. and Gessner, U. (2017) Aspirin plus Pseudoephedrine (Aspirin Complex) for the Treatment of Symptoms of Upper Respiratory Tract Infection. Open Journal of Respiratory Diseases, 7, 25-40. https://doi.org/10.4236/ojrd.2017.71004

Received: October 1, 2016

Accepted: February 4, 2017

Published: February 7, 2017

Copyright $\odot 2017$ by authors and Scientific Research Publishing Inc. This work is licensed under the Creative Commons Attribution International License (CC BY 4.0).

http://creativecommons.org/licenses/by/4.0/

\begin{abstract}
Upper respiratory tract infections or common colds are a multi-symptom disease which is usually symptomatically treated with fixed dose multi-active ingredient medicinal products which are commonly used as non-prescription and over the counter. However, the active ingredients combined require a particular and clinically sound justification. Analgesics and decongestant can be combined to treat simultaneously the prominent symptoms cold-related pain (e.g. headache, muscle aches and pains), fever, inflammationand nasal/sinus congestion. This overview provides a summary of the evidence supporting the combination of acetylsalicylic acid (aspirin) and pseudoephedrine available in the common cold product Aspirin ${ }^{\circledR}$ Complex.
\end{abstract}

\section{Keywords}

Aspirin, Acetylsalicylic Acid, Pseudoephedrine, Dissolution, Pharmacokinetic, Upper Respiratory Tract Infection, Clinical Studies

\section{Introduction}

Acute upper respiratory tract infections (URTI) which are commonly known as common cold and flu are one of the most common diseases of humans with adults suffering from 2 - 5 symptomatic infections each year and school-children from 7 - 10 each year [1]. Over 200 serologically different viral types from eight different groups of viruses are responsible for human URTI's with the rhinoviruses being the most common cause [1] [2]. The symptoms of URTI's are so common that self-diagnosis is normal amongst the general public [3] and symptomatic self-treatments with nonprescription medicines are the most common 
therapy.

Common cold and flu are multi-symptom illnesses which justify the use of multi-ingredient combination products [4]. The rationale for the fixed combination products for common cold and flu is practicable, logical and reasonable when some requirements are fulfilled [5]. First the simultaneous appearance of the symptoms is crucial. The constellation of symptoms makes the common cold and flu unique among common diseases as no other condition has such a range of symptoms that occur simultaneously. Each symptom can be treated with a separate active ingredient, but multi-symptom relief, using combination products with multiple active ingredients is recommended by many pharmacists [6]. The time course of the progression of the symptoms is characterized by the early simultaneous appearance of sore throat, headache, body aches and pains and nasal related symptoms later followed by cough [4] [7] [8] [9]. The fixed combination product should be pharmacologically plausible and based on valid therapeutic principles [5]. The possibility of interactions between the active pharmaceutical ingredients of the fixed combination needs to be considered and the release of the active substances for the symptomatic treatment of common cold and flu has to be adjusted to the presence of the symptoms.

Fixed combinations of analgesics and decongestant are commonly used for symptomatic treatment of common cold and flu [4] [10] [11]. The rationale for the treatment is that nasal congestion and pain commonly occur simultaneously and that a combination medicine provides a simplification of therapy compared to use of an analgesic and a decongestant as mono-therapies [4].

Aspirin ${ }^{\circledR}$ Complex is a fixed combination medicinal product consisting of the analgesic active $500 \mathrm{mg}$ acetylsalicylic acid and the decongestant active $30 \mathrm{mg}$ pseudoephedrine. Acetylsalicylic acid (aspirin, ASA) is a nonsteroidal anti-inflammatory drug with analgesic, antipyretic and anti-inflammatory properties. It's efficacy in fever [12] and acute pain [13] has been frequently shown with randomized controlled clinical trials in several pain model [14]-[17]. Pseudoephedrine (PSE) is an $\alpha$-sympathomimetic vasoconstrictor given orally for the relief of nasal congestion. The efficacy and safety of PSE is proven and well established [18]. Aspirin ${ }^{\circledR}$ Complex is provided as a granule formulation in sachets. It is used for the symptomatic treatment of cold-related pain and fever and congestion of the nasal passages and ostia of the paranasal sinuses caused by upper respiratory tract infections in doses of $1-2$ sachets per administration with a daily dose of up to 6 sachets, corresponding to a maximum daily dose of $3000 \mathrm{mg}$ acetylsalicylic acid and $180 \mathrm{mg}$ pseudoephedrine.

This review presents in vitro dissolution data and clinical evidence of pharmacokinetics, efficacy and safety of this medicinal product and a justification of this multi-ingredient combination product for the symptomatic treatment of common cold and flu.

\section{Dissolution}

Medicinal product formulation and its excipients have a substantial impact on 
bioavailability of active pharmaceutical ingredients and in vitro dissolution of a formulated drug provides useful information about its biopharmaceutical properties. The dissolution properties of Aspirin ${ }^{\circledR}$ Complex granules for oral suspension containing $500 \mathrm{mg}$ acetylsalicylic acid and $30 \mathrm{mg}$ pseudoephedrine (Bayer, Leverkusen, Germany), were compared with BoxaGrippal ${ }^{\circledR}$ tablets containing $200 \mathrm{mg}$ ibuprofen and $30 \mathrm{mg}$ pseudoephedrine (Boehringer Ingelheim, Ingelheim am Rhein, Germany), and Grippostad ${ }^{\circledR} \mathrm{C}$ capsules containing 200 paracetamol, $150 \mathrm{mg}$ ascorbic acid, $25 \mathrm{mg}$ caffeine and $2.5 \mathrm{mg}$ chlorpheniramine maleate (STADA, Bad Vilbel, Germany) at three different dissolution media ( $\mathrm{pH}$ 1.2: $0.1 \mathrm{~N} \mathrm{HCl}, \mathrm{pH}$ 4.5: $0.05 \mathrm{M}$ acetate buffer, $\mathrm{pH}$ 6.8: $0.05 \mathrm{M}$ phosphate buffer) as requested by governance guidelines [19]. The dissolution study was carried out using Hanson dissolution apparatus model Vision Elite 8 (Hanson Research, Chatsworth, CA, USA) configured for apparatus II (paddles) with eight vessels of $1 \mathrm{~L}$ capacity each. Each of the three products was tested 36 times (12 vessels at each of the $3 \mathrm{pHs}$ for each product). Each vessel contained $500 \mathrm{~mL}$ of the dissolution media and the paddle rotation rate was $50 \mathrm{rpm}$. The dissolution media were heated to $37^{\circ} \mathrm{C} \pm 0.5^{\circ} \mathrm{C}$. Five milliliter samples were withdrawn at $1,3,6$, 15,30 , and 45 minutes. Change in sample volumes were factored into the calculations. The concentration and percent dissolved for the active pharmaceutical ingredients in each sample were determined using reversed phase high performance liquid chromatography. The analgesic compound acetylsalicylic acid, ibuprofen and paracetamol and the decongestant compounds pseudoephedrine and chlorpheniramine were determined and compared.

Evaluation of the dissolution release profiles of the three products studied shows differences in release rates for both the analgesic component and the decongestant component of the medicinal products. Figure 1 and Figure 2 show the respective dissolution profiles at $\mathrm{pH} 1.2,4.5$ and 6.8. Dissolution of acetylsalicylic acid (ASA) in Aspirin ${ }^{\circledR}$ Complex is already at around $100 \%$ within 5 minutes regardless of the $\mathrm{pH}$. BoxaGrippal ${ }^{\circledR}$ tablet's ibuprofen (IBU) dissolution is low at $\mathrm{pH} 1.2$ and 4.5 (less than $20 \%$ after 45 minutes), but higher at $\mathrm{pH}$ 6.8 (80\% dissolution after 30 minutes). Grippostad ${ }^{\circledR} \mathrm{C}$ capsule's paracetamol (PAR) dissolution is $\mathrm{pH}$ independent, but only reaches approximately $40 \%$ release within 45 minutes. Aspirin ${ }^{\circledR}$ Complex's pseudoephedrine (PSE) is instantly at $100 \%$ dissolved at all $3 \mathrm{pHs}$, whereas pseudoephedrine from BoxaGrippal ${ }^{\circledR}$ tablet is around $80 \%$ - 90\% dissolved after 15 minutes and achieves close to $100 \%$ after 45 minutes. Dissolution of chlorpheniramine (CPM) in Grippostad ${ }^{\circledR} \mathrm{C}$ capsule is low with only about $50 \%-70 \%$ release after 45 minutes in the three pHs. Overall Aspirin ${ }^{\circledR}$ Complex provides rapid dissolution of both the analgesic and decongestant active ingredients which results in fast bioavailability and quick onset of action.

\section{Pharmacokinetics}

\subsection{Drug-Drug Interaction Study}

Fixed combination products have to provide evidence that the active ingredients 


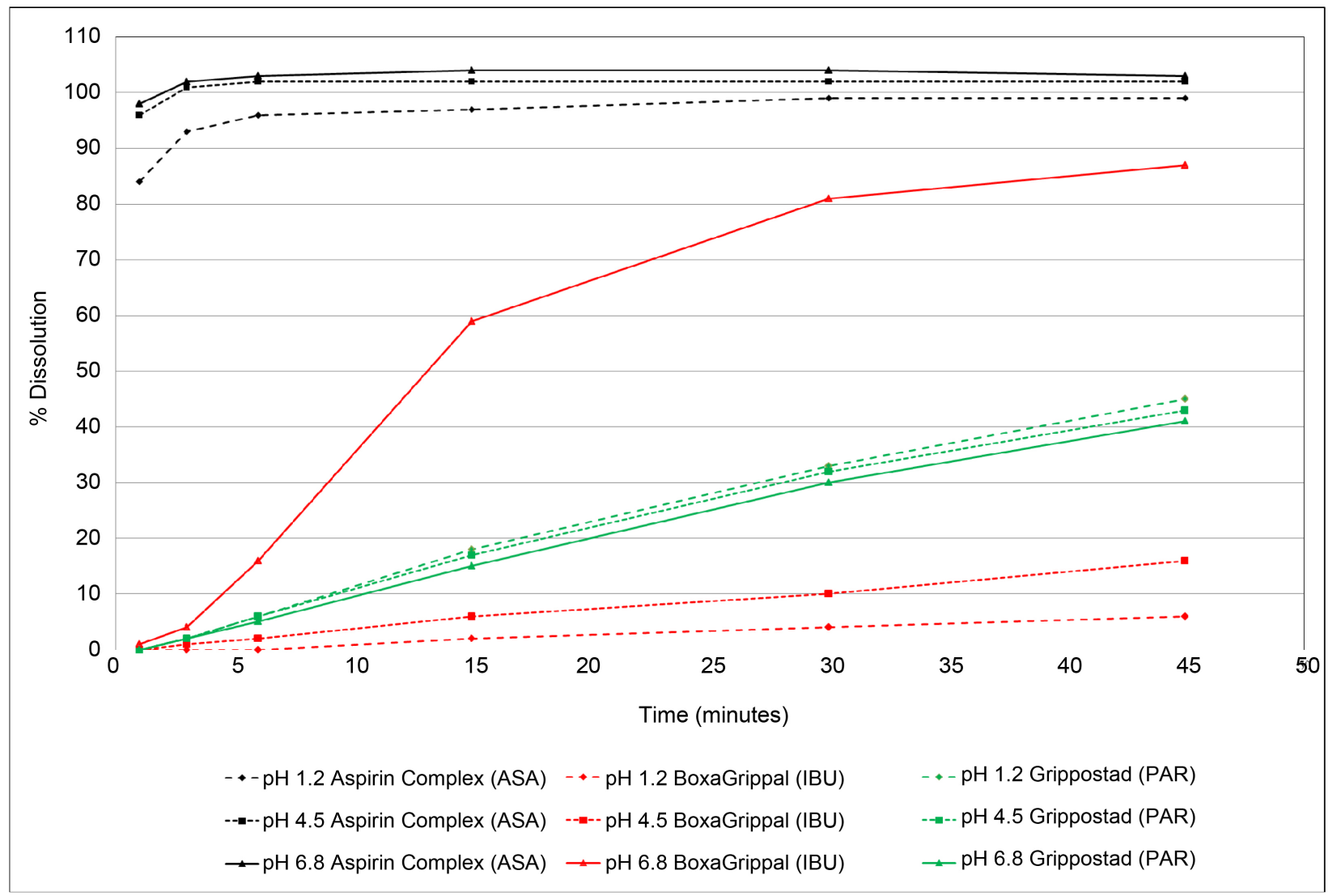

Figure 1. Dissolution profiles of analgesic compounds.

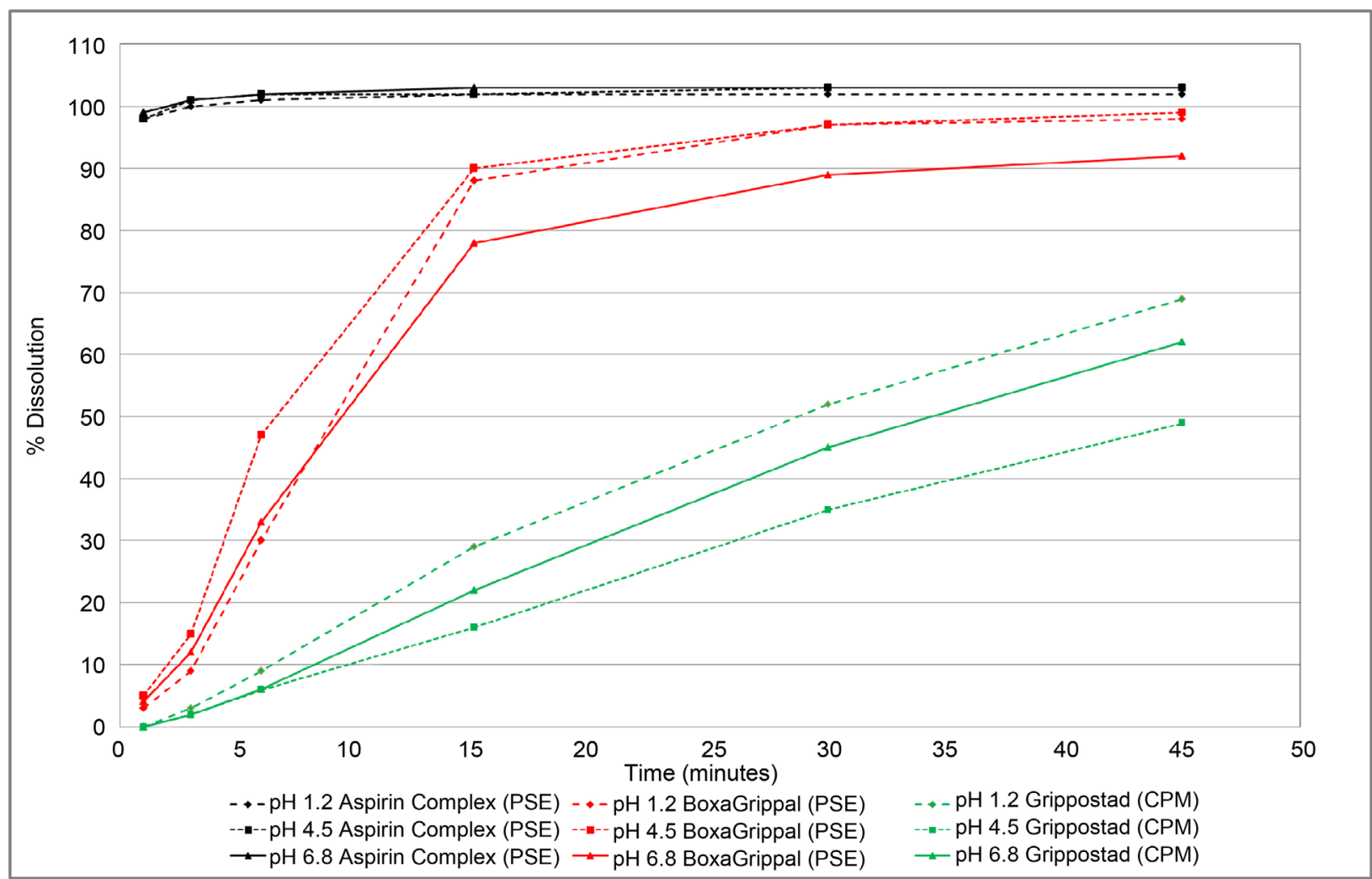

Figure 2. Dissolution profiles of decongestant compounds. 
are not interacting and consequently not impacting the bioavailability of its active ingredients. The fixed combination product Aspirin ${ }^{\circledR}$ Complex has been proven for potential interactions of the actives ASA and PSE in a 3-fold crossover study with 12 healthy male subjects [20]. Each subject received in a randomly assigned order $500 \mathrm{mg}$ ASA plus $30 \mathrm{mg}$ PSE and $500 \mathrm{mg}$ ASA and $30 \mathrm{mg}$ PSE. The median age of the subjects was 29 years (range: 21 - 42 years). The results of interaction study for maximum plasma concentrations $\left(\mathrm{C}_{\max }\right)$, area under the curve (AUC) and time to maximum plasma concentrations $\left(\mathrm{T}_{\max }\right)$ are presented in Table 1 . With respect to the pharmacokinetic parameters $C_{\max }$, AUC and $\mathrm{T}_{\max }$ equivalence for the analytes ASA, salicylic acid (SA, hydrolysis product and active metabolite of ASA) and PSE can be concluded. Therefore a drug-drug interaction of the two active ingredients in Aspirin Complex ${ }^{\circledast}$ can be excluded.

\subsection{Bioavailability Studies}

The overall bioavailability of Aspirin ${ }^{\circledR}$ Complex has been evaluated in three additional pharmacokinetic studies. All studies were unblinded cross-over studies with 24 evaluable patients conducted in 2004 in Germany (study 1, IMP 11757) [21], with 30 evaluable patients conducted in 2011 in Canada (study 2, IMP 15,776) [22] and with 26 evaluable patients conducted in 2011 in Australia (study 3, IMP 14,892) [23]. All studies were sponsored by Bayer AG and followed the same standard protocol for pharmacokinetic studies provided by the sponsor. The mean and median results for $\mathrm{C}_{\max }, \mathrm{AUC}$ and $\mathrm{T}_{\max }$ for the individual studies and the statistical summary across studies are presented in Table 2. Two studies compared Aspirin ${ }^{\circledR}$ Complex with non-marketed experimental formulations (IMP 14892, IMP 11757). Study IMP 15776 compared Aspirin ${ }^{\circledR}$ Complex with the flavoured formulation Aspirin ${ }^{\circledR}$ Complex Hot Drink. Data from the two bioequivalent formulations are presented.

Acetylsalicylic acid has a relatively low $\mathrm{T}_{\max }$. The maximum plasma concentration is already achieved within 15.6 minutes. The first and active metabolite of

Table 1. Interaction study and pharmacokinetic parameters of ASA plus PSE (Aspirin ${ }^{\circledR}$ Complex), ASA and PSE (geometric means (standard deviation); $\mathrm{T}_{\max }$ units = median and ranges; $\mathrm{NA}=$ not applicable).

\begin{tabular}{ccccc}
\hline $\begin{array}{c}\text { Pharmacokinetic } \\
\text { parameter }\end{array}$ & Analyte & ASA plus PSE & ASA & PSE \\
\hline $\mathrm{C}_{\max }(\mu \mathrm{g} / \mathrm{mL})$ & $\mathrm{ASA}$ & $12.04(1.21)$ & $12.81(1.20)$ & $\mathrm{NA}$ \\
$\mathrm{AUC}(\mathrm{mg} \times \mathrm{h} / \mathrm{L})$ & $\mathrm{ASA}$ & $5.52(1.16)$ & $5.45(1.15)$ & $\mathrm{NA}$ \\
$\mathrm{T}_{\max }($ hours $)$ & $\mathrm{ASA}$ & $0.21(0.17-0.33)$ & $0.17(0.08-0.25)$ & $\mathrm{NA}$ \\
$\mathrm{C}_{\max }(\mu \mathrm{g} / \mathrm{mL})$ & $\mathrm{SA}$ & $29.44(1.24)$ & $32.88(1.23)$ & $\mathrm{NA}$ \\
$\mathrm{AUC}(\mathrm{mg} \times \mathrm{h} / \mathrm{L})$ & $\mathrm{SA}$ & $114.04(1.28)$ & $123.10(1.33)$ & $\mathrm{NA}$ \\
$\mathrm{T}_{\max }(\mathrm{hours})$ & $\mathrm{SA}$ & $0.67(0.42-1.50)$ & $0.50(0.42-1.00)$ & $\mathrm{NA}$ \\
$\mathrm{C}_{\max }(\mu \mathrm{g} / \mathrm{L})$ & $\mathrm{PSE}$ & $130(1.14)$ & $\mathrm{NA}$ & $140(1.36)$ \\
$\mathrm{AUC}(\mu \mathrm{g} \times \mathrm{h} / \mathrm{L})$ & $\mathrm{PSE}$ & $960(1.23)$ & $\mathrm{NA}$ & $900(1.25)$ \\
$\mathrm{T}_{\max }(\mathrm{hours})$ & $\mathrm{PSE}$ & $0.67(0.33-2.00)$ & $\mathrm{NA}$ & $0.50(0.33-1.50)$ \\
\hline
\end{tabular}


Table 2. Bioavailability studies and pharmacokinetic parameters ASA and PSE of Aspirin ${ }^{\circledR}$ Complex $\left({ }^{*}\right.$ for individual studies $\mathrm{C}_{\max }$ and $\mathrm{AUC}_{0-\infty}$ geometric mean/geometric $\mathrm{CV}(\%)$ (range) and $\mathrm{T}_{\max }$ median (range), ${ }^{\star *}$ for summary $\mathrm{C}_{\max }$ and $\mathrm{AUC}_{0-\infty}$ geometric mean/SD (range), and $\mathrm{T}_{\max }$ median (range)).

\begin{tabular}{|c|c|c|c|c|c|c|c|c|c|c|}
\hline \multirow{2}{*}{$\begin{array}{l}\text { Study } \\
\text { No.* }\end{array}$} & \multirow{2}{*}{ Treatment } & \multicolumn{3}{|c|}{ Pseudoephedrine } & \multicolumn{3}{|c|}{ Acetylsalicylic acid } & \multicolumn{3}{|c|}{ Salicylic acid } \\
\hline & & $\mathrm{C}_{\max }(\mu \mathrm{g} / \mathrm{L})$ & $\begin{array}{c}\mathrm{AUC}_{0-\infty} \\
(\mu \mathrm{g} \times \mathrm{h} / \mathrm{L})\end{array}$ & $\mathrm{T}_{\max }$ (hours) & $\mathrm{C}_{\max }(\mu \mathrm{g} / \mathrm{mL})$ & $\begin{array}{c}\mathrm{AUC}_{0-\infty} \\
(\mu \mathrm{g} \times \mathrm{h} / \mathrm{mL})\end{array}$ & $\mathrm{T}_{\max }$ (hours) & $\mathrm{C}_{\max }(\mu \mathrm{g} / \mathrm{mL})$ & $\begin{array}{c}\mathrm{AUC}_{0-\infty} \\
(\mu \mathrm{g} \times \mathrm{h} / \mathrm{mL})\end{array}$ & $\mathrm{T}_{\max }$ (hours) \\
\hline $\begin{array}{c}\text { IMP } \\
14892\end{array}$ & $\begin{array}{c}\text { Aspirin } \\
\text { Complex } \\
\text { compared to } \\
\text { experimental } \\
\text { product }\end{array}$ & $\begin{array}{c}147 / 21.6 \\
(92.7-230)\end{array}$ & $\begin{array}{c}1110 / 27.4 \\
(666-2215)\end{array}$ & $\begin{array}{c}0.83 \\
(0.33-4.00)\end{array}$ & $\begin{array}{l}13.00 / 22.3 \\
(8.9-24.5)\end{array}$ & $\begin{array}{c}7.87 / 18.4 \\
(5.5-11.3)\end{array}$ & $\begin{array}{c}0.31 \\
(0.17-0.53)\end{array}$ & $\begin{array}{c}24.30 / 15.6 \\
(17.9-31.4)\end{array}$ & $\begin{array}{c}111.0 / 29.0 \\
(72.5-209)\end{array}$ & $\begin{array}{c}0.83 \\
(0.33-2.00)\end{array}$ \\
\hline $\begin{array}{c}\text { IMP } \\
15776\end{array}$ & $\begin{array}{c}\text { Aspirin } \\
\text { Complex } \\
\text { Hot Drink }\end{array}$ & $\begin{array}{c}154 / 29.6 \\
(90.3-291)\end{array}$ & $\begin{array}{c}921 / 24.2 \\
(625-1886)\end{array}$ & $\begin{array}{c}0.83 \\
(0.25-3.0)\end{array}$ & $\begin{array}{l}15.86 / 35.1 \\
(8.1-30.5)\end{array}$ & $\begin{array}{c}8.94 / 15.5 \\
(6.7-11.7)\end{array}$ & $\begin{array}{c}0.25 \\
(0.15-0.50)\end{array}$ & $\begin{array}{c}27.75 / 17.9 \\
(18.1-37.6)\end{array}$ & $\begin{array}{l}155.5 / 32.5 \\
(92.4-326)\end{array}$ & $\begin{array}{c}0.67 \\
(0.25-1.50)\end{array}$ \\
\hline $\begin{array}{l}\text { IMP } \\
15776\end{array}$ & $\begin{array}{l}\text { Aspirin } \\
\text { Complex }\end{array}$ & $\begin{array}{c}143 / 29.6 \\
(85.8-257)\end{array}$ & $\begin{array}{c}952 / 26.1 \\
(648-2035)\end{array}$ & $\begin{array}{c}0.83 \\
(0.33-3.0)\end{array}$ & $\begin{array}{l}14.97 / 33.3 \\
(5.4-24.6)\end{array}$ & $\begin{array}{c}9.17 / 15.0 \\
(7.0-12.6)\end{array}$ & $\begin{array}{c}0.25 \\
(0.17-0.67)\end{array}$ & $\begin{array}{c}27.08 / 15.0 \\
(19.7-36.7)\end{array}$ & $\begin{array}{l}152.4 / 31.8 \\
(96.8-331)\end{array}$ & $\begin{array}{c}0.91 \\
(0.33-2.00)\end{array}$ \\
\hline $\begin{array}{l}\text { IMP } \\
11757\end{array}$ & $\begin{array}{c}\text { Aspirin } \\
\text { Complex } \\
\text { compared to } \\
\text { experimental } \\
\text { product }\end{array}$ & $\begin{array}{c}122 / 24.7 \\
(78.3-196.7)\end{array}$ & $\begin{array}{c}966 / 26.2 \\
(611-1678)\end{array}$ & $\begin{array}{c}0.83 \\
(0.33-3.0)\end{array}$ & $\begin{array}{l}12.57 / 34.0 \\
(7.0-29.5)\end{array}$ & $\begin{array}{l}6.34 / 20.1 \\
(4.7-9.7)\end{array}$ & $\begin{array}{c}0.25 \\
(0.17-0.35)\end{array}$ & $\begin{array}{c}31.32 / 21.7 \\
(21.1-43.5)\end{array}$ & $\begin{array}{l}133.8 / 22.8 \\
(85.2-192)\end{array}$ & $\begin{array}{c}0.83 \\
(0.42-2.00)\end{array}$ \\
\hline & mmary** & $\begin{array}{c}141 / 1.1 \\
(122-154)\end{array}$ & $\begin{array}{c}985 / 1.1 \\
(921-1110)\end{array}$ & $\begin{array}{c}0.83 \\
(0.83-0.83)\end{array}$ & $\begin{array}{c}14.03 / 1.1 \\
(12.57-15.86)\end{array}$ & $\begin{array}{c}8.00 / 1.2 \\
(6.34-9.17)\end{array}$ & $\begin{array}{c}0.26 \\
(0.25-0.31\end{array}$ & $\begin{array}{c}27.50 / 1.1 \\
(24.30-31.32)\end{array}$ & $\begin{array}{c}137 / 1.1 \\
(111.0-155.5)\end{array}$ & $\begin{array}{c}0.81 \\
(0.67-0.91)\end{array}$ \\
\hline
\end{tabular}

ASA is salicylic acid (SA) which is obtained by enzymatic hydrolysis in the presystemic circulation due to esterases [24]. Like ASA, SA has analgesic, antipyretic and anti-inflammatory properties [24]. SA's maximum plasma concentration is obtained within 48.6 minutes. The $\mathrm{T}_{\max }$ of PSE ( 49.8 minutes) highly fits with SA. Therefore it can be concluded that the bioavailability of of the two active ingredients is fast and well adjusted. Both actives of Aspirin ${ }^{\circledR}$ Complex provide simultaneously sufficient plasma concentrations.

\section{Efficacy and Safety Information}

\subsection{Clinical Efficacy}

The clinical efficacy of Aspirin ${ }^{\circledR}$ Complex has been evaluated in four randomized controlled clinical trials [10] [25] [26] [27]. The key points of these studies are summarized in Table 3. All studies were placebo-controlled, double-blind and sponsored by Bayer AG, Germany. Two studies also included a paracetamol (PAR) plus PSE combination as an active comparator. Two studies investigated Aspirin ${ }^{\circledR}$ Complex using a study design which is following the guidance given in the European Medicines Agency (EMA) Guideline for Fixed Combination Medicinal Products [5], i.e. the combination has been tested versus the single active ingredients. The 4 studies have been conduct in the United States and in the European Union between 1997 and 2012. All studies have been done in patients with URTI and investigated the efficacy of the product Aspirin ${ }^{\circledR}$ Complex in pain and nasal congestion. The studies 1 and 2 provided evidence that the two active ingredients in the formulation act independently as a decongestant (study 1) [25] and as a pain reliever (study 2) [26]. Study 1 showed that nasal congestion 
Table 3. Summary of Aspirin ${ }^{\circledR}$ Complex efficacy studies (ASA $=$ aspirin, PSE $=$ pseudoephedrine, PAR = paracetamol, URTI $=$ upper respiratory tract infection, CSR = Clinical Study Report).

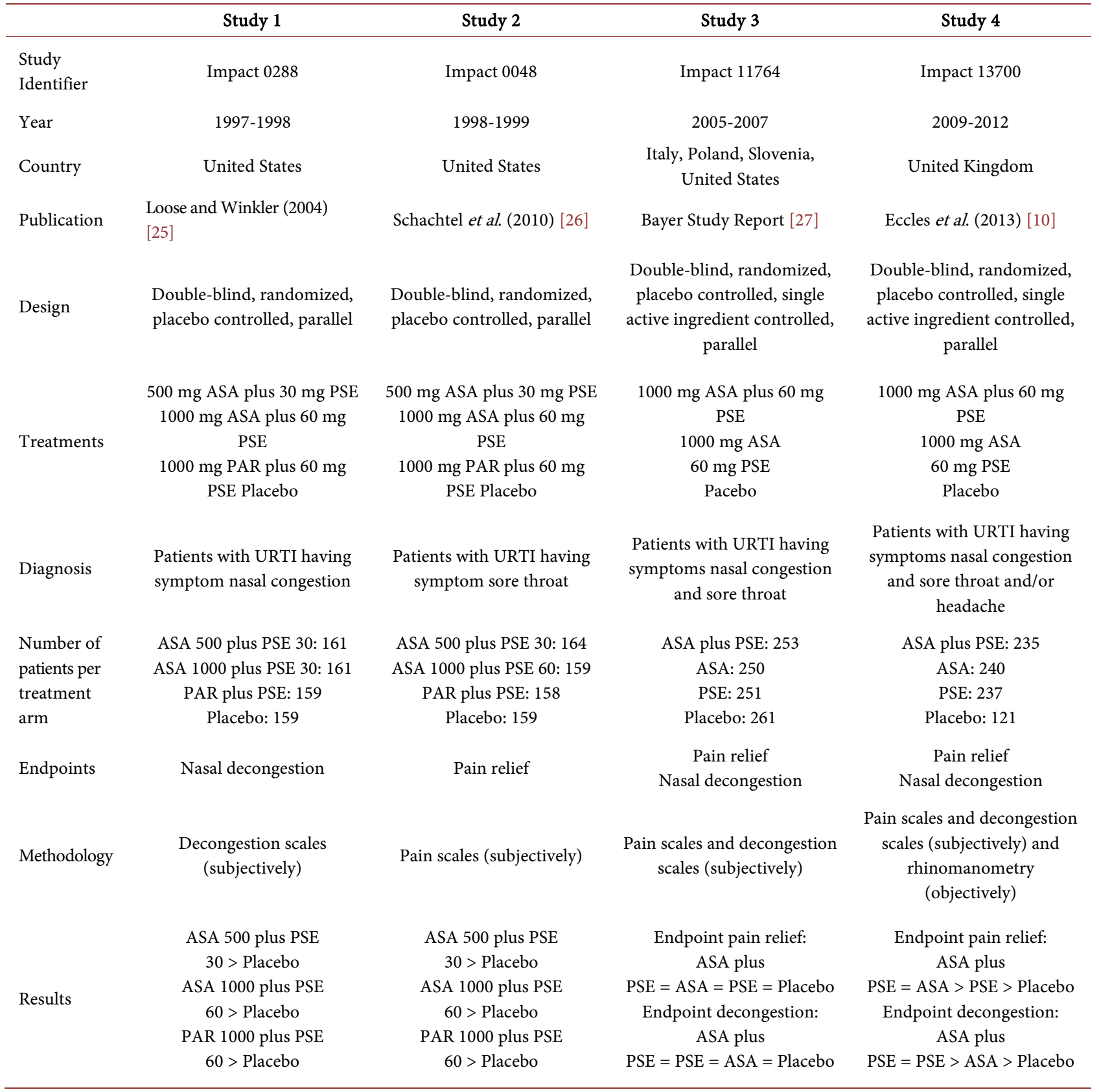

was statistically significantly reduced compared to placebo for treatment ASA 1000 plus PSE 60, ASA 500 plus PSE 30 and PAR 1000 plus PSE 60. Numerical differences between ASA 1000 plus PSE 60 and PAR 1000 and PSE 60 were insignificant. As expected the lower dose of PSE in the treatment ASA 500 plus PSE 30 provided a somewhat lower (but still significant vs. placebo) decongestion [25]. Study 2 showed that sore throat pain was statistically significantly reduced compared to placebo for treatment ASA 1000 plus PSE 60, ASA 500 plus PSE 30 and PAR 1000 plus PSE 60. Secondary endpoints provided some evidence of a positive dose-response of ASA and showed some difference between 
ASA 1000 and PAR 1000 when combined with a 60-mg dose of PSE [26].

In order to address requirements of the European Health Authority EMA stated in the guideline for fixed medicinal combination products [5], study 3 compared the combination with the individual active ingredients. This study had two primary objectives: relief of nasal congestion of the combination vs. ASA alone and relief of sore throat of the combination vs. PSE alone. The study did not meet its two primary objectives and failed to demonstrate a statistically significant superiority of ASA plus SE vs. ASA in nasal congestion and of ASA plus PSE vs. PSE in sore throat. Also comparisons with placebo (ASA plus PSE vs. placebo, ASA vs. placebo, PSE vs. placebo) did not reveal statistically significant differences [27]. This suggests that the study may have lacked assay sensitivity; variability has to be taken into consideration because this study was done in 79 centers in 4 countries and the duration of symptoms at baseline was longer than 96 hours. This is different from studies 1 and 2 which were done in 2 centers each and the duration of symptoms at baseline was 24 hours. The subsequent study 4 also investigated the combination in comparison to its individual active ingredients. This study was done is a single center, using patients having symptoms no longer than 72 hours and using an objective measurement of nasal congestion (measurement of nasal airflow resistance by posterior rhinomanometry) and categorical congestion scales. Pain was assessed for the combination of sore throat pain and/or headache using categorical pain intensity and pain relief scales [10]. The study showed statistically significant differences between ASA plus PSE vs. ASA for the endpoint nasal congestion (Figure 3) and between ASA plus PSE vs. PSE for the endpoint pain (Figure 4). Furthermore comparisons of ASA vs. PSE for pain and PSE vs. ASA for nasal congestion showed statistically significant differences. All active treatments differed from placebo for the respective endpoints [10]. Results of the objective measurement of nasal decongestion

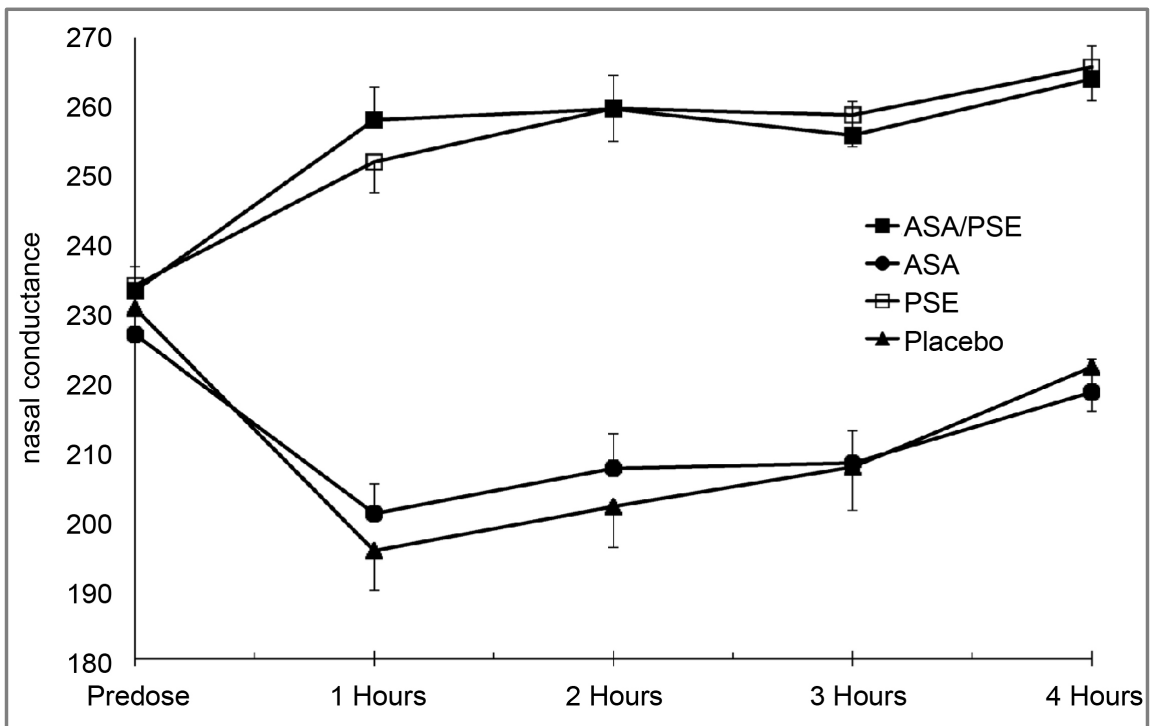

Figure 3. Study 4: mean $\left( \pm\right.$ SEM) nasal airflow conductance $\left(\mathrm{cm}^{3}\right.$ second) before and up to 4 hours after dosing [10]. 




Figure 4. Study 4: mean $( \pm$ SEM) pain relief score before and up to 4 hours after dosing $[10]$.

have been confirmed by subjective measurements using categorical scales (Figure 5).

\subsection{Clinical Safety}

In order to assess the clinical safety and tolerability of Aspirin ${ }^{\circledR}$ Complex an integrated individual patient data analysis of the patient reported and physician assessed adverse events of the two multiple-dose placebo-controlled studies 10 and 27 were conducted. Treatment duration of the two studies was 3 - 5 days. The integrated analysis patient population took a median daily dose of $3000 \mathrm{mg}$ ASA and $180 \mathrm{mg}$ PSE which corresponds with the maximum daily dose. The total dose over the treatment period was $8000 \mathrm{mg}$ ASA and $480 \mathrm{mg}$ PSE. Aspirin ${ }^{\circledR}$ Complex and placebo incidences of adverse events and adverse drug reactions and the Odds Ratios for the most important side effects are listed in Table 4. These side effects include the gastrointestinal system related to the active aspirin and the central nervous system related to the active pseudoephedrine. Generally incidences of side effects of Aspirin ${ }^{\circledR}$ Complex are close to placebo level and the side effects seen are all listed in the Aspirin ${ }^{\circledR}$ Complex label. Although none of the Odds Ratios between Aspirin ${ }^{\circledR}$ Complex and placebo reached statistical significance some trends confirm the label. Interestingly no gastrointestinal hemorrhages, ulcerations and perforations and no increase in blood pressure and cardiac effects have been detected.

\subsection{Non-Interventional Studies}

While efficacy and safety of a drug can only be demonstrated in well-controlled randomized clinical studies, community pharmacy based non-interventional studies (NIS) are a valid instrument for the evaluation of usage patterns, effectiveness and tolerability under real-life conditions [28]. Three NIS with Aspirin ${ }^{\circledR}$ 


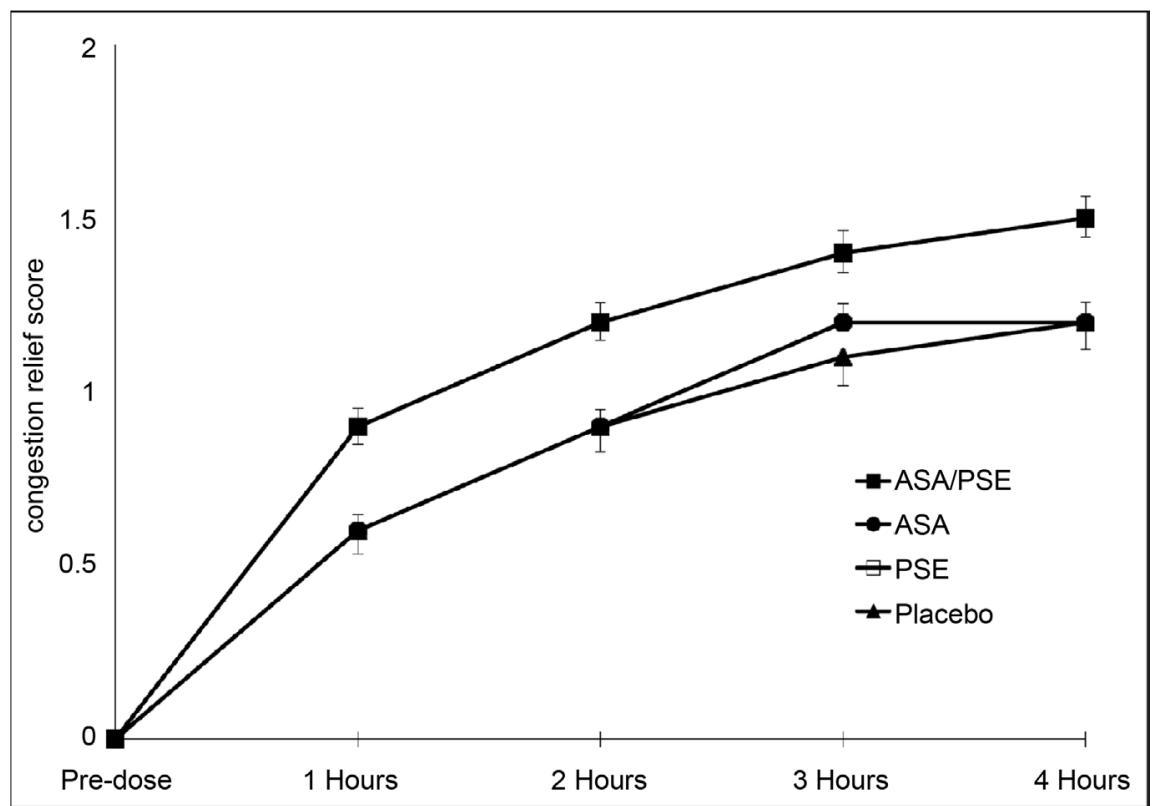

Figure 5. Study 4: mean ( \pm SEM) nasal congestion relief score before and up to 4 hours after dosing [10].

Table 4. Aspirin ${ }^{\circledR}$ Complex integratedsafety and tolerability analysis $(\mathrm{CI}=$ confidence interval).

\begin{tabular}{|c|c|c|c|c|c|c|}
\hline \multirow{3}{*}{ Category } & \multicolumn{2}{|c|}{ Incidences } & \multirow[b]{2}{*}{$\begin{array}{c}\text { Odds Ratio } \\
(95 \% \mathrm{CI})\end{array}$} & \multicolumn{2}{|c|}{ Incidences } & \multirow[b]{2}{*}{$\begin{array}{c}\text { Odds Ratio } \\
(95 \% \mathrm{CI})\end{array}$} \\
\hline & $\begin{array}{l}\text { Aspirin }^{\circledR} \\
\text { Complex } \\
\mathrm{N}=375\end{array}$ & $\begin{array}{l}\text { Placebo } \\
\mathrm{N}=317\end{array}$ & & $\begin{array}{l}\text { Aspirin }^{\circledR} \\
\text { Complex } \\
\mathrm{N}=375\end{array}$ & $\begin{array}{l}\text { Placebo } \\
\mathrm{N}=317\end{array}$ & \\
\hline & \multicolumn{3}{|c|}{ Adverse Events } & \multicolumn{3}{|c|}{ Drug-Related Adverse Events } \\
\hline All Adverse Events & $13.6 \%$ & $11.0 \%$ & $\begin{array}{c}1.20 \\
(0.75-1.92)\end{array}$ & $5.9 \%$ & $3.8 \%$ & $\begin{array}{c}1.59 \\
(0.76-3.35)\end{array}$ \\
\hline $\begin{array}{c}\text { All } \\
\text { Gastrointestinal } \\
\text { Adverse Events }\end{array}$ & $7.5 \%$ & $4.4 \%$ & $\begin{array}{c}1.76 \\
(0.90-3.48)\end{array}$ & $4.8 \%$ & $2.2 \%$ & $\begin{array}{c}2.32 \\
(0.93-5.82)\end{array}$ \\
\hline Dyspepsia & $0.5 \%$ & $0.3 \%$ & $\begin{array}{c}1.56 \\
(0.12-20.84)\end{array}$ & $0.3 \%$ & $0.3 \%$ & $\begin{array}{c}0.83 \\
(0.04-16.13)\end{array}$ \\
\hline Nausea & $3.5 \%$ & $1.9 \%$ & $\begin{array}{c}1.83 \\
(0.69-4.89)\end{array}$ & $2.4 \%$ & $0.9 \%$ & $\begin{array}{c}2.70 \\
(0.70-10.38)\end{array}$ \\
\hline $\begin{array}{c}\text { Minor } \\
\text { gastrointestinal } \\
\text { disorders }^{\star}\end{array}$ & $6.4 \%$ & $3.5 \%$ & $\begin{array}{c}1.82 \\
(0.87-3.83)\end{array}$ & $4.3 \%$ & $1.9 \%$ & $\begin{array}{c}2.41 \\
(0.91-6.40)\end{array}$ \\
\hline $\begin{array}{l}\text { Central nervous } \\
\text { system } \\
\text { stimulation }^{\star *}\end{array}$ & $1.9 \%$ & $0.9 \%$ & $\begin{array}{c}1.67 \\
(0.43-6.57)\end{array}$ & $0.5 \%$ & $0.6 \%$ & $\begin{array}{c}0.85 \\
(0.12-6.05)\end{array}$ \\
\hline
\end{tabular}

${ }^{\star}$ Includes heartburn, nausea, vomiting, abdominal pain. ${ }^{* \star}$ Includes insomnia and somnolence.

Complex have been performed in Germany including a total of 3333 patients who purchased the product in a community pharmacy for the treatment of symptoms of a self-diagnosed common cold [29] [30] [31]. 
About two third of the patients were female with a mean age of 39 years. About half of the patients treated their cold symptoms with a first single dose of one sachet, the other half with two sachets, dependent on the severity of the symptoms. The majority of the patients complained of four or more symptoms at the same time before the start of treatment, thus fulfilling the requirement for treatment with a combination product [4]. The most frequent symptoms were blocked nose, headache, sore throat, runny nose, muscle aches and pain and sinus symptoms. Within the entire treatment course of 3 days a total of only eight sachets were used demonstrating responsible self-medication. The severity of the symptoms (from $0=$ not present to $4=$ very severe) was recorded by the patients before and up to 120 minutes after intake of the first dose of Aspirin ${ }^{\circledR}$ Complex for the most typical cold symptoms (nasal congestion, runny nose, sore throat, headache, muscle aches \& pains, sinus symptoms, fatigue, fever/raised temperature and cough). Substantial improvement of the symptoms occurred within the first 15 - 30 minutes after intake of the medication, especially for those symptoms which are expected to be relieved by ASA and PSE like blocked nose and cold associated pain symptoms (Figure 6).

After intake of the first dose of the combination product $72 \%$ of the patients reported a duration of the treatment effect of $4-6$ hours, 13\% of more than 6 hours.The impairment in activities of daily living caused by the cold complaints was analysed before and 2 hours after the first application [32]. While 55.5\% of the patients reported moderate or severe impairment before application of medicine, only $10.2 \%$ were impaired two hours after use.Patient satisfaction with Aspirin ${ }^{\circledR}$ Complex was assessed by the Treatment Satisfaction Questionnaire for

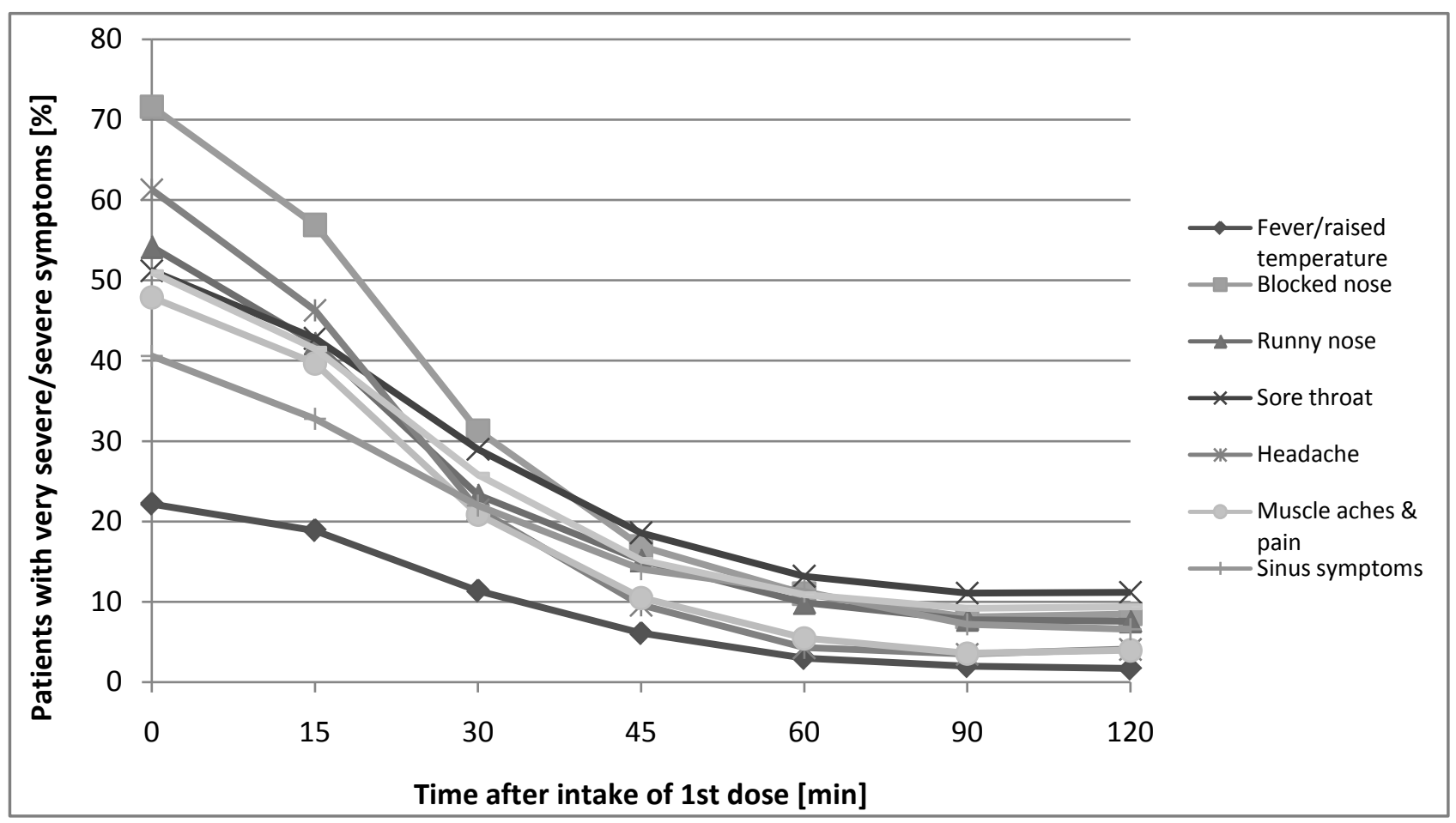

Figure 6. Percentage of patients with very severe/severe symptoms 0 - $120 \mathrm{~min}$ after intake of the first dose of medication [32]. 
Medication (TSQM version II, linguistically validated German version, [33]). Overall, $94.0 \%$ of the patients were somewhat to extremely satisfied with the medication on a seven-point Likert scale. In line with this, about $90 \%$ of the patients rated the effectiveness and the tolerability of the medication as "very good" or "good".

In total, $11.9 \%$ of the patients reported adverse events. The most common adverse events were classified according to the MedDRA ${ }^{\circledR}$ (Medical Dictionary for Regulatory Activities) system organ classes: gastrointestinal disorders (8.2\%; mainly stomach problems, nausea and dyspepsia), cardiac disorders (1.5\%; mainly palpitations), psychiatric disorders (1.6\%; mainly insomnia), nervous system disorders (1.5\%; mainly dizziness) and general disorders and administration site conditions (1\%; mainly fatigue). Adverse events in other organ classes were below $1 \%$. No serious gastrointestinal adverse events such as bleeding or ulcers were reported.

\section{Discussion}

Common cold or URTI is the most common human disease. Because of the high incidence of the disease in children and adults, over a life time of 75 years subjects can expect to suffer at least 150 or more bouts of common cold as the incidence in adults is $2-5$ colds a year and $7-10$ colds a year in school-children (1). If each case of URTI has a duration of 5 days of symptoms this would translate into suffering over two years of bothersome symptoms in a lifetime. It is therefore not surprising that there is a great demand for effective symptomatic treatments for URTI. Most cases of URTI are dealt with by self-medication with readily available over the counter (OTC) medications and it is important to the consumer that these medicines are safe and effective, and ideally that they can treat a range of symptoms as URTI is a multi-symptom disease [3] [4].

Aspirin ${ }^{\circledR}$ Complex is a combination of aspirin and pseudoephedrine that safely and effectively treats a range of URTI symptoms such as nasal congestion, and pain related symptoms such as sore throat, headache, muscle aches and pains, as well as fever [10] [25] [26].

The presented data shows the high availability of the active ingredients, provides evidence that the pharmacokinetics of the combination of aspirin and pseudoephedrine are compatible, and demonstrates that both actives of Aspirin ${ }^{\circledR}$ Complex provide simultaneously sufficient plasma concentrations to treat both pain and congestion symptoms. The pharmacokinetics of the two active ingredients are also demonstrated to be independent with no interaction between aspirin and pseudoephedrine.

The efficacy of the combination medicine of aspirin and pseudoephedrine has been demonstrated in three high quality double blind placebo controlled studies [10] [25] [26] and these support similar studies demonstrating the efficacy of the single ingredients of aspirin on pain related symptoms of URTI [16] and pseudoephedrine on nasal congestion [18]. These studies also support the safety and tolerability of the medicinal product. Under the label condition the product clearly 
has a positive benefit-risk ratio.

In addition to the clinical studies, usage pattern, effectiveness and tolerability of Aspirin ${ }^{\circledR}$ Complex has been evaluated under real-life conditions in three community pharmacy based non-interventional studies [29] [30] [31]. The results suggest that the patients use the product in accordance with the instructions given in the package leaflet. Symptom relief started instantly and was substantial within 15 - 30 minutes after intake. About $90 \%$ of the patients assessed the effectiveness and tolerability of the product as "very good" or "good". In general, $94 \%$ of the patients were satisfied with the product's performance. Adverse events reported by the patients are in the same range as in the clinical trials.

The rationale for treatment of URTI with multi-ingredient combination products has already been discussed in a recent publication and the same rationale applies to the combination of aspirin and pseudoephedrine in Aspirin ${ }^{\circledR}$ Complex [4].

An important part of the rationale is that URTI is a multi-symptom disease with many symptoms occurring simultaneously [7]. A URTI may commence with a single symptom such as a scratchy, dry, irritating sensation in the throat. However, after a period of usually a day, the disease develops to include additional typical symptoms of URTI such as runny nose, sneezing, sore throat, headache, blocked nose or nasal congestion, cough, sinus pain, watery eyes, loss of appetite, muscle aches and pains, chilliness, low-grade fever, sleep problems and malaise [3]. A combination of aspirin and pseudoephedrine will provide symptomatic relief to the patient for half of these symptoms as the combination relieves nasal congestion, sore throat, headache, sinus pain, muscle aches and pains, chilliness, and fever.

The safety and efficacy of any medical treatment is first dependent on compliance of the patient to take their medicines as directed, as overdosing may lead to an increased risk of side effects occurring and under-dosing may mean that the treatment is ineffective in treating the disease state. A combination of aspirin and pseudoephedrine provides a simpler dosing regimen than taking separate medicines. This improves compliance and makes treatment easier for the patient than taking two separate medicines. In any medical treatment it is self-evident that the simpler the dosing regimen the more likely it is that the medicines will be taken in the correct dose at the correct time. The combination of aspirin and pseudoephedrine in a single dose formula offers the patient the convenience of treating multiple symptoms with a single product and may therefore promote improved compliance to the treatment. This helps support both patient safety and optimal efficacy of the medicine. The combination of aspirin and pseudoephedrine in a single treatment ensures that the two medicines are taken together and since the pharmacokinetics of the two medicines is similar with similar bioavailability this ensures an optimal treatment of multiple URTI symptoms.

No evidence has been found in the literature and the studies presented in this 
review that the combination of aspirin and pseudoephedrine is inherently less safe than single-active ingredient medicines. Aspirin and pseudoephedrine have different mechanisms of action and they do not interact with each other. There is no evidence for any compounding of toxicity by combining aspirin and pseudoephedrine in a single treatment.

\section{Conclusion}

The combination of aspirin and pseudoephedrine provides a safe, effective, and convenient way of treating multiple symptoms of URTI when used as directed. As with any OTC medicine, it is important that the patient is made aware of any contra indications for the combination therapy and the correct dosing schedule. Dissolution properties and pharmacokinetic characteristics of Aspirin ${ }^{\circledR}$ Complex provide support for product efficacy as shown in several randomized placebo controlled clinical studies. Efficacy and safety data as well as real life evidence data supports the overall positive benefit risk ratio of Aspirin ${ }^{\circledR}$ Complex.

\section{Acknowledgements}

R.E. acts as a consultant for Bayer AG, Leverkusen, Germany and acted as principal investigator for Bayer sponsored studies. M. V. and U. G. are employees of Bayer AG, Leverkusen, Germany.

\section{References}

[1] Johnston, S. and Holgate, S. (1996) Epidemiology of Viral Respiratory Infections. In: Myint, S. and Taylor-Robinson, D., Eds., Viral and Other Infections of the Human Respiratory Tract, Chapman \& Hall, London, 1-38.

https://doi.org/10.1007/978-94-011-7930-0_1

[2] Weber, O. (2009) The Role of Viruses in the Etiology and Pathogenesis of Common Cold. In: Eccles, R. and Webber, O., Eds., Common Cold, BirkhauserVerlag, Basel, 107-147. https://doi.org/10.1007/978-3-7643-9912-2_5

[3] Eccles, R. (2005) Understanding the Symptoms of the Common Cold and Influenza. The Lancet Infectious Diseases, 5, 718-725. https://doi.org/10.1016/S1473-3099(05)70270-X

[4] Eccles, R., Fietze, I. and Rose, U.B. (2014) Rationale for Treatment of Common Cold and Flu with Multi-Ingredient Combination Products for Multi-Symptom Relief in Adults. Open Journal of Respiratory Disease, 4, 73-82. https://doi.org/10.4236/ojrd.2014.43011

[5] European Medicines Agency. Committee for Medicinal Products for Human Use (2009) Guideline on Clinical Development of Fixed Combination Medicinal Products. DocRef CPMP/EWP/240/95 Rev1, London.

[6] Sirois, J. and Ferreri, S. (2013) OTC Combination Products in Pharmacist-Assisted Self-Care. Pharmacy Today, 19, 49-53.

[7] Jackson, G., Dowling, H., Spiesman, I. and Boand, A. (1958) Transmission of the Common Cold to Volunteers under Controlled Conditions. 1 The Common Cold as a Clinical Entity. JAMA Internal Medicine, 101, 267-278.

[8] Gwaltney Jr., J.M., Hendley, J.O., Simon, G. and Jordan Jr., W.S. (1967) Rhinovirus Infections in an Industrial Population. II. Characteristics of Illness and Antibody 
Response. JAMA, 202, 494-500. https://doi.org/10.1001/jama.1967.03130190100014

[9] Tyrrell, D.A.J., Cohen, S. and Schlarb, J.E. (1993) Signs and Symptoms in Common Cold. Epidemiology and Infection, 111, 143-156.

https://doi.org/10.1017/S0950268800056764

[10] Eccles, R. and Voelker, M. (2013) Analgesic and Decongestant Efficacy of the Combination of Aspirin with Pseudoephedrine in Patients with Symptoms of Upper Respiratory Tract Infection. Clinical Pharmacology in Drug Development, 3, 118 125. https://doi.org/10.1002/cpdd.39

[11] Eccles, R., Jawad, M., Jawad, S., et al. (2006) Efficacy of a Paracetamol-Pseudoephedrine Combination for Treatment of Nasal Congestion and Pain-Related Symptoms in Upper Respiratory Tract Infection. Current Medical Research and Opinion, 22, 2411-2418. https://doi.org/10.1185/030079906X154105

[12] Bachert, C., Chuchalin, A.G., Eisebitt, R., Netayzhenko, V.Z. and Voelker, M. (2005) Aspirin Compared with Acetaminophen in the Treatment of Fever and Other Symptoms of Upper Respiratory Tract Infection in Adults: A Multicenter, Randomized, Double-Blind, Double-Dummy, Placebo Controlled, Parallel-Group, SingleDose, 6-Hour Dose-Ranging Study. Clinical Therapeutics, 27, 993-1003. https://doi.org/10.1016/j.clinthera.2005.06.002

[13] Hersh, E.V., Moore, P.A. and Ross, G.L. (2000) Over-the-Counter Analgesics and Antipyretics: A Critical Assessment. Clinical Therapeutics, 22, 500-548. https://doi.org/10.1016/S0149-2918(00)80043-0

[14] Steiner, T.J., Lange, R. and Voelker, M. (2003) Aspirin in Episodic Tension-Type Headache: Placebo-Controlled Dose-Ranging Comparison with Paracetamol. Cephalalgia, 23, 59-66. https://doi.org/10.1046/j.1468-2982.2003.00470.x

[15] Diener, H.C., Lampl, C., Reimitz, P. and Voelker, M. (2006) Aspirin in the Treatment of Acute Migraine Attacks. Expert Review of Neurotherapeutics, 6, 563-573. https://doi.org/10.1586/14737175.6.4.563

[16] Eccles, R., Loose, I., Jawad, M. and Nyman, L. (2003) Effects of Acetylsalicylic Acid on Sore Throat Pain and Other Pain Symptoms Associated with Acute Upper Respiratory Tract Infection. Pain Medicine, 4, 118-124. https://doi.org/10.1046/j.1526-4637.2003.03019.x

[17] Cooper, S.A. and Voelker, M. (2012) Evaluation of Onset of Pain Relief from Micronized Aspirin in Dental Pain Model. Inflammopharmacology, 20, 233-242. https://doi.org/10.1007/s10787-012-0121-0

[18] Eccles, R. (2007) Substitution of Phenylephrine for Pseudoephedrine as a Nasal Decongestant. An Illogical Way to Control Methamphetamine Use. British Journal of Clinical Pharmacology, 63, 10-14. https://doi.org/10.1111/j.1365-2125.2006.02833.x

[19] European Medicines Agency (2010) Committee for Medicinal Products for Human Use. Guideline on the Investigation of Bioequivalence, CPMP/QWP/EWP/1401/98 Rev.1, London.

[20] Bayer Health Care Clinical Study Report (2000) Open, Randomized Three-Factorial (Treatment-Period-Sequence), Three-Treatment, Three-Period Latin Square Clinical Study for Comparison of a Fixed Combination of $500 \mathrm{mg}$ Acetylsalicylic Acid/30 mg Pseudoephedrine versus Each of the Singe Active Ingredients (Pharmacokinetic Interaction Study) in 12 Healthy Male Volunteers. Report No. PH-29594.

[21] Bayer Health Care Clinical Study Report (2005) Open, Randomized Three-Factorial (Treatment-Period-Sequence), Two-Treatment, Two-Period, Cross-Over Clinical Bioequivalence-Study for Comparison of a Fixed Combination of 500 mg Acetylsalicylic Acid/30 mg Pseudoephedrine versus a Newly Developed Caplet Formulation 
Containing 500 mg Acetylsalicylic Acid/30 mg Pseudoephedrine in 24 Healthy Male Volunteers. Report No. PH-33966.

[22] Bayer Health Care Clinical Study Report (2012) A Pharmacokinetic Trial of Aspirin plus Pseudoephedrine Granules with Eucalyptus versus Aspirin plus Pseudoephedrine Granules in Healthy Adult Subjects. Report No. PH-36738.

[23] Bayer Health Care Clinical Study Report (2012) An Open Label Crossover Pharmacokinetic Trial of Aspirin plus Pseudoephedrine Dry Granules versus Aspirin plus Pseudoephedrine Granules in Healthy Adult Subjects. Report No. PH-36689.

[24] Schroer, K. (2009) Acetylsalicylic Acid. Wiley, Weinheim.

[25] Loose, I. and Winkler, M. (2004) Clinical, Double-Blind, Placebo-Controlled Study Investigating the Combination of Acetylsalicylic Acid and Pseudoephedrine for the Symptomatic Treatment of Nasal Congestion Associated with Common Cold. Drug Research, 54, 513-521.

[26] Schachtel, B.P., Voelker, M., Sanner, K.M., Gagney, D., Bey, M., Schachtel, E.J. and Becka, M. (2010) Demonstration of the Analgesic Efficacy and Dose-Response of Acetylsalicylic Acid with Pseudoephedrine. Journal of Clinical Pharmacology, 50, 1429-1437. https://doi.org/10.1177/0091270009360978

[27] Bayer Health Care Clinical Study Report (2009) A Pivotal, Placebo Controlled, Phase III Study to Compare Efficacy and Tolerability of a Fixed Combination, Containing $500 \mathrm{mg}$ ASA and $30 \mathrm{mg}$ Pseudoephedrine, in Comparison to Its Single Components in Patients with Sore Throat and Nasal Congestion. Report No. CC03008.

[28] Weingärtner, U. (2005) Die Anwendungsbeobachtung in der Apotheke als Instrument der Arzneimittelforschung für ein Arzneimittelnach der Zulassung: Methodik und Evaluierungan ausgewählten Praxisbeispielen. Govi Verlag, Eschborn.

[29] Gessner, U. and Petersen-Braun, M. (2005) AWB Aspirin Complex . Bewährt gegen Halsweh, Schnupfen und erkältungsbedingten Schmerzen. Pharm Ztg, 150, 35-40.

[30] Grunthal, S. and Gessner, U. (2008) Symptomatische Therapie von Erkältungskrankheiten mit Kombinationspräparaten. Pharm Ztg, 153, 230-237.

[31] Theurer, C. and Gessner, U. (2011) Aspirin Complex. Zufriedene Patienten bei der Selbstmedikation von Erkältungsbeschwerden. Pharm Ztg, 156, 56-61.

[32] Gessner, U. and Petersen-Braun, M. (2010) Kombination aus ASS und Pseudoephedrin positiv. Deutsche Apotheker Zeitung, 150, 119-122.

[33] Atkinson, M.J., Kumar, R., Cappelleri, J.C. and Hass, S.L. (2005) Hierarchical Construct Validity of the Treatment Satisfaction Questionnaire for Medication (TSQM Version II) among Outpatient Pharmacy Consumers. Value Health, 8, 9-24. https://doi.org/10.1111/j.1524-4733.2005.00066.x 
Submit or recommend next manuscript to SCIRP and we will provide best service for you:

Accepting pre-submission inquiries through Email, Facebook, LinkedIn, Twitter, etc. A wide selection of journals (inclusive of 9 subjects, more than 200 journals)

Providing 24-hour high-quality service

User-friendly online submission system

Fair and swift peer-review system

Efficient typesetting and proofreading procedure

Display of the result of downloads and visits, as well as the number of cited articles Maximum dissemination of your research work

Submit your manuscript at: http://papersubmission.scirp.org/

Or contact ojrd@scirp.org 